\title{
"They are not the words of a rational man": ecstatic prophecy in Montanism
}

\begin{abstract}
Both the historiographical analysis and the ancient documents about the Christian movement known as Montanism place paramount importance on prophecy, visions, and ecstasy. The theological refutation of Montanist teaching and doctrine in the heresiological sources was almost entirely shaped by the attribution of deceitfulness and error to the experience of ecstatic prophecy. Even though some oracles uttered by the Montanist prophets are preserved, the most detailed description of their ecstasy is conveyed by the reports of the heresiologists. The present paper attempts to reconstruct the Montanist prophetic experience, comparing descriptions of Montanist ecstasy in the heresiological texts with other reports about ecstatic prophecy. More specifically, an analysis of the linguistic components that heresiologists used to describe ecstasy is contrasted with the vocabulary of other texts which illustrate the same basic model of religious experience. Finally, the conclusions draw attention to the discourses and interpretations of ecstatic prophecy related by different observers.
\end{abstract}

\section{Introduction}

In this paper, I would like to investigate the description of ecstasy as it occurs in the most relevant heresiological reports about Montanism. Surprisingly, we know of the importance that ecstasy assumes for the Montanists not through the direct voice of the three founders of this religious movement but rather through the reports of those authors who wrote polemical treatises against it. Since all the books that Montanists wrote are lost (see Eusebius, Historia Ecclesiastica V.18.5 and VI.20.3; Hippolytus, Refutatio omnium haeresium VIII.19.1) and none of the scant number of oracles preserved hints specifically of the significance of ecstasy in the Montanist religious experience, we must rely on the heresiological sources in order to find traces of the role played by ecstasy itself in the shaping process of Montanist teachings. Therefore, I will reconstruct the Montanist prophetic experience through a re-evaluation of the available literary narrative.

I will start with a preliminary chapter aimed at illustrating the rhetorical framework which defines the most relevant literary representations of Montanist ecstatic prophecy (in the sense of ecstasy occurring in conjunction with prophecy). After that, I will compare the descriptions of Montanist ecstasy in the 
heresiological texts (chapter 3) with other reports about it (chapters 4 and 5), and on such basis I identify a set of key features that may constitute a more reliable outline of this particular religious experience as it occurred in Montanist circles. More specifically, an analysis of the linguistic components that heresiologists used to describe the ecstatic behavior of Montanus, Prisca and Maximilla is contrasted with the vocabulary of other texts which illustrate the same basic model of religious experience. As a result, this contrast between different discourses and interpretations of ecstatic prophecy related by different observers shows how a single religious experience assumes various contours and nuances according to the particular narrator's theological view. ${ }^{1}$

\section{Montanist ecstasy according to the heresiological tradition}

In Book IX (chapter 33) of the chronicle of Michael Syrus (end of the 12th century), there is a curious account of the persecution of the adherents of Montanism (see Gero 1977) which also includes two specific sections dedicated to the destruction, by John of Ephesus, Justinian's emissary, of the relics of Montanus and his two prophetesses, and to the story of the conflict between Apollos and Montanus: ${ }^{2}$

In the land of Phrygia there was a village called Pepuza, where the Montanists had a bishop and clerics. They called it Jerusalem and killed the Christians. John of Asia went there and burned their place of assembly with fire by the order of the emperor. And there was found in this building a great reliquary of marble, which was sealed with lead and bound together with iron hoops. Upon it was written, 'Of Montanus and his women'. And when it was opened, there were found the bodies of Montanus and of his women, Maximilla and Priscilla, with plates of gold upon their mouths. And they were ashamed because of this, when they saw the stinking bones of the one they called 'the Spirit'. And they were told, 'Are you not ashamed that you are going astray after this polluted one,

1 See Segal 2006, 32: “This suggests forcefully that religious experiences are strongly influenced by the cultural context in which they occur, that the group itself through its leaders decides what is a valid or invalid experience, and that adepts learn which experiences to validate or valorize. It is not too much to suggest that in the process they learn how to generate the correct kind of physical states and extinguish those that are considered unhelpful. This means, of course, that mysticism is not a solitary experience; it is an experience that is social".

2 For the Syriac text, Gero uses the edition of Chabot 1910. The English translation of the following passages is by Gero himself. 
and that you call him “The Spirit”? Because a spirit has no flesh and bones.' Then they burned the bones. The Montanists made sounds of lamentation and mourning, and they said, 'Now the world is overthrown and will perish'. And they found their abominable books and burned them. And the building was purified and became a church.

Concerning this Montanus, Apollos, the companion of Paul, wrote in a letter that he was the son of Simon the magician, and when his father died by the instrumentality of Peter, he fled from Rome and set out to disturb the world. Then Apollos, (moved) by the Spirit, came to where he was and saw him sitting and leading men astray. And he stood and rebuked him and said, 'O, enemy of God, may the Lord rebuke you!'. And Montanus began to contend, and said, 'What is between me and you, Apollos? If you are a prophet, so am I, and if you are an apostle, so am I, and if you are a teacher, so am I'. Apollos said, 'May your mouth be silenced, in the name of the Lord!'. And immediately he became speechless, and was not ever again able to speak. The people believed in our Lord, and were baptized. And they overturned the seat of Montanus, and he fled and escaped. The end of this story and of the other.

These two excerpts from the general account of Montanism are considerably relevant for the overall understanding of ecstatic prophecy as a fundamental religious experience within the Montanist doctrine. Generally speaking, all the heresiological sources focusing on the "New Prophecy" ${ }^{3}$ include a detailed description of the ecstatic behavior of Montanus, Prisca, and Maximilla. Indeed, the relationship between prophecy and "false" ecstasy is the main issue in Christian polemics against them, starting from the anonymous author (end of the 2nd century) who was asked to write a report on Montanist prophets after taking part in an oral controversy against them (Eus. HE V.16.2).

In this sense, the above-quoted excerpts from the chronicle of Michael Syrus present the typical rhetorical framework ${ }^{4}$ which defines every single literary representation ${ }^{5}$ of the Montanist religious experience as they occurred in different polemical texts: the key-term "spirit" appears in both passages, and in each case, it assumes different meanings according to the specific character to whom it refers. Thus, when referring to the representatives of the Montanist side, it seems to require a further qualification in order to define its polemical use. Indeed, a "Montanist spirit" is always associated with the moral concepts of corruption and seduction: "And they were ashamed because of this, when they saw

3 See Eus. HE V.16.4 for the supposed (self-?) designation “(New?) Prophecy” attributed by the Montanists to their movement.

4 See Lieu 2015, for a detailed description of the mechanisms of a literary/rhetorical construction of heresy. For a specific attempt to use the idea of "rhetorical construction" in the investigation of Montanism (especially focusing on the construction of identity and otherness in Epiphanius' Panarion), see Nasrallah 2003.

5 See Le Boulluec 1985, for a detailed survey of the theoretical principles at the heart of a "heresiological representation". 
the stinking bones of the one they called 'the Spirit'. And they were told, 'Are you not ashamed that you are going astray after this polluted one, and that you call him The Spirit?"' (Michael Syrus, Chronicle IX.33). By contrast, a “catholic spirit" does not seem to need any further clarification. For example, when the author says in the following lines, "Then Apollos, (moved) by the Spirit, came to where he was and saw him sitting and leading men astray”, Apollos is represented as moved by the spirit, which is revealed to be the real spirit, the right one, as proven by the absence of any further linguistic clarification. In addition, Apollos is also represented as coming to where Montanus was and observing him in the act of deceiving his followers. Ultimately, according to the author, Apollos represents the good, while Montanus is the evil.

However, when Apollos tries to rebuke Montanus, the latter replies by saying, "What is between me and you, Apollos? If you are a prophet, so am I". This is the most significant statement of the overall passage, because it clearly underlines Montanus' unequivocal perception of the intentional demarcation between true and false prophecy operated by the church authorities in the 2nd century. Indeed, the heresiological tradition tends to develop " [. . .] as a Christian literary discourse to define and refute theological error as a means of ensuring correct belief and exclusive identity" (see Lyman 2007, 297). This is to say it develops as the expression of the social dynamics of excluding the other (through charges of immorality) in order to reinforce its own identity, considered as the depository of true faith in opposition to the false teachings of the heretics.

The following short passage from the account of Montanism in Epiphanius' Panarion is representative of this overall rhetorical tendency:

By comparing what they have said with the teachings of the Old and New Testaments which are true, and which have been delivered and prophesied in truth - let us determine which is really prophecy, and which false prophecy. ${ }^{6}$

The vocabulary of "truth" is here emphatically stressed, demonstrating how the rhetorical strategy of constructing heresy is conducted through the definition "of true beliefs and practices versus false beliefs and practices" (Gilhus 2015, 153). The latter is in the end the preliminary statement leading to the consequent final assertion of the supremacy of "orthodoxy".

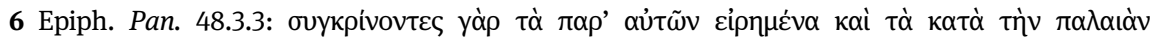

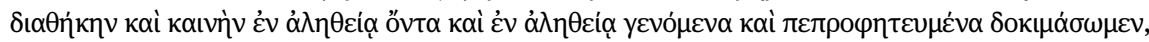

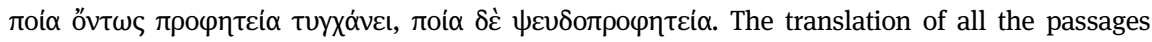
(here and elsewhere) from Panarion is by F. Williams.

7 On the notion of orthodoxy within the rhetorical discourse on the creation of identities see Iricinschi and Zellentin 2008 (especially the contribution on Montanism by Karen King); for
} 
This attribution of the character of mendacity and corruption reserved to the image of the heretic - a Montanist one in this case - is immediately associated with the very specific aspect of the Montanist religious experience of prophecy. In the opening passage of his account of Montanism, Epiphanius maintains that Montanists:

[...] accept every scripture of the Old and the New Testaments, and affirm the resurrection of the dead as well. But they boast of having Montanus for a prophet, and Priscilla and Maximilla for prophetesses, and have lost their wits by paying heed to them. They agree with the holy catholic church about the Father, the Son and the Holy Spirit, but have separated themselves by 'giving heed to seducing spirits and doctrines of devils' [...]. ${ }^{8}$

The "error" of the Phrygian prophets does not consist in a theological distortion of the fundamental principles of the Christian faith, such as the affirmation of the resurrection of the dead or the acceptance of the Trinity. Their error is related neither to the aspect of doctrine, nor to Christian belief. It essentially concerns the practice of ecstatic prophecy instead. Particularly representative of this conflict is the reference to "losing wits", which constitutes the starting point of the whole refutation of Montanism that follows in Panarion 48. Epiphanius attacks Montanus and Maximilla because they are false prophets and their ecstasy does not conform to the tradition of the church from the beginning: it is so extreme and uncontrolled that it appears to be a direct manifestation of frenzy. These prophets, Epiphanius says, have lost their minds, and so have their followers; therefore, their words sound incomprehensible and strange, like the words of a man who is not rational: ${ }^{9}$

But when the Phrygians profess to prophesy, it is plain that they are not sound of mind and rational. Their words are ambiguous and odd, with nothing right about them [...] For the Holy Spirit never spoke in him. Such expressions as 'I fly', and 'strike', and 'watch', and 'The Lord distracteth men's hearts', are the utterances of an ecstatic. They are not the words of a rational man, but of someone of a different stamp from the Holy Spirit who spoke in the prophets. ${ }^{10}$

the issues related to heresiology, see also Shelton 2015; Aragione 2013; Cameron 2005; Pourkier 1992.

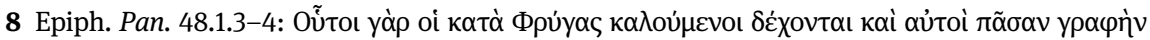

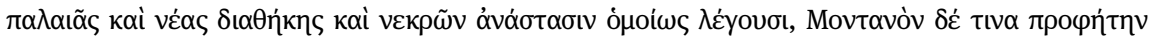

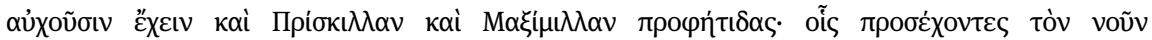

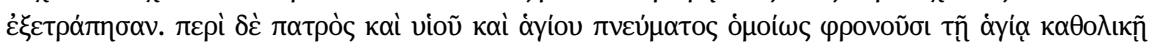

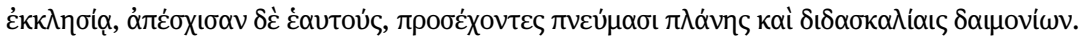

9 See Dell'Isola 2015 for the description of false prophecy in Epiphanius' Panarion.

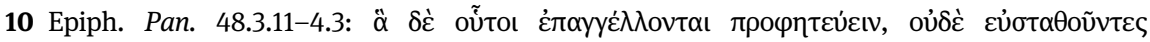

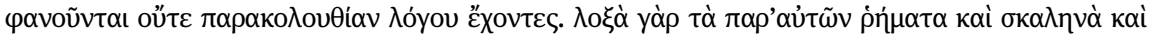


The anonymous author in Eusebius also followed exactly the same pattern when asked to give a description of the Montanist movement:

There they say that a recent convert called Montanus, when Gratus was proconsul of Asia, in the unbounded lust of his soul for leadership gave access to himself to the adversary, became obsessed, and suddenly fell into frenzy and convulsions. He began to be ecstatic and to speak and to talk strangely, prophesying contrary to the custom which belongs to the tradition and succession of the church from the beginning. Of those who at that time heard these bastard utterances some were vexed, thinking that he was possessed by a devil and by a spirit of error, and was disturbing the populace [. . .]. ${ }^{11}$

The language here belongs to the same semantic field which is at the heart of the account in Panarion $48:^{12}$

\begin{tabular}{|c|c|}
\hline Eus. HE V.16.7-8 & Epiph. Pan. 48.3.11-4.3 \\
\hline $\begin{array}{l}\text { - "[...] became obsessed, and suddenly } \\
\text { fell into frenzy and convulsions. He } \\
\text { began to be ecstatic [...]"; “[...] thinking } \\
\text { that he was possessed by a devil and by } \\
\text { a spirit of error [...]”; }\end{array}$ & $\begin{array}{l}\text { - "But when the Phrygians profess to } \\
\text { prophesy, it is plain that they are not } \\
\text { sound of mind and rational"; }\end{array}$ \\
\hline $\begin{array}{l}\text { - “[ . .] and to speak and to talk strangely } \\
{[\ldots] " ; \text { “ [...] these bastard utterances }} \\
{[\ldots] \text {; }}\end{array}$ & $\begin{array}{l}\text { - "Their words are ambiguous and odd, } \\
\text { with nothing right about them [...]"; } \\
\text { "Such expressions }[\ldots . .] \text { are the } \\
\text { utterances of an ecstatic"; }\end{array}$ \\
\hline
\end{tabular}

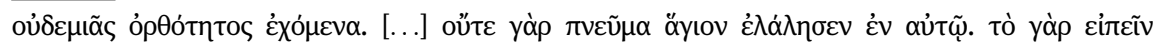

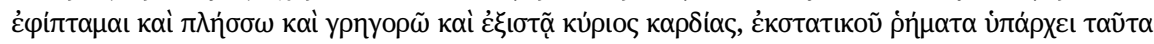

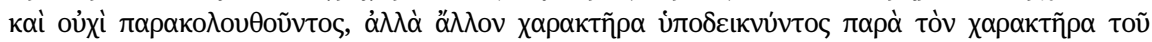

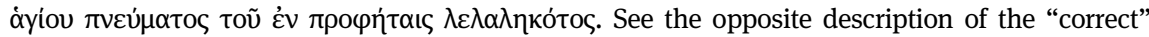
Christian ecstasy in Pan. 48.3.4-3.9: "A prophet always spoke with composure and understanding, and delivered his oracles by the Holy Spirit's inspiration. He said everything with a sound mind [...]. And who can deny that Daniel was filled with all wisdom and in possession of his senses?"

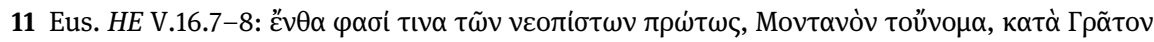

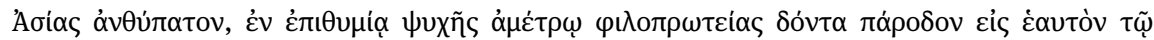

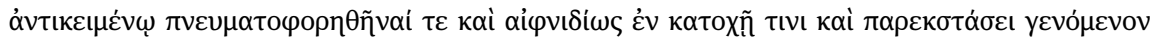

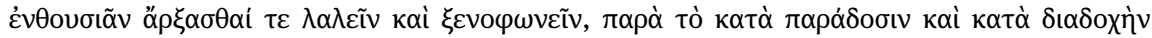

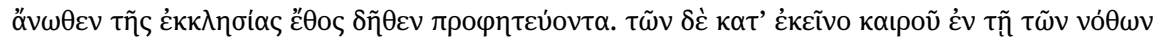

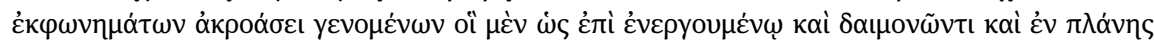

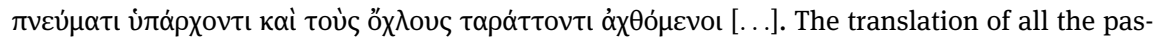
sages (here and elsewhere) from Historia Ecclesiastica is by K. Lake.

12 See Mader 2012, 96-144, who argues for a comparison (and textual relationship) between the two main reports on Montanism in Eusebius and Epiphanius. 
(continued)

Eus. HE V.16.7-8

- “[...] prophesying contrary to the custom which belongs to the tradition and succession of the church from the beginning".
Epiph. Pan. 48.3.11-4.3

- "They are not the words of a rational man, but of someone of a different stamp from the Holy Spirit who spoke in the prophets".

In both cases, the description appears to be articulated in three main arguments:

1) A prophetic ecstasy characterized by a loss of rationality, self-possession, and composure;

2) A prophetic discourse which reflects the irrationality of the ecstasy: words are incomprehensible, meaningless, and strange;

3) A Montanist prophecy (both in practice and discourse) which is the opposite of "traditional" Christian prophecy.

It is the final consideration of the opposition to ecclesiastical tradition that is relevant to the description of Montanist ecstasy in the heresiological sources. Ecstatic prophecy was certainly a familiar religious experience within 2ndcentury Christianity (see Aune 1983, 291-313). In this sense, the description of Montanist prophetic speech as strange, inarticulate, and incomprehensible utterance could be also interpreted as a reference to glossolalia. Speaking in tongues was a common practice within the early Christian communities, as indicated by the fact that Paul, in 1 Corinthians, tries to moderate ecstatic enthusiasm so that prophetic utterance could be clearer and understandable. Therefore, it could be likely that heresiologists refer to glossolalic speech when they characterize the prophecy of Montanus, Prisca and Maximilla as involving "strange and incomprehensible words" (Bremmer 2016, 11-18). However, as Forbes says, "Though it is certainly true that Montanist prophecy was characterized by ecstasy (in the modern sense), and occasionally by oracular obscurity, there is no unambiguous evidence whatsoever that it took glossolalic form. Indeed, the evidence of Eusebius, who knows of collections of Montanist oracles and actually cites the contents of some of them, makes it luminously clear that these oracles were delivered in plain Greek. Nor is there any suggestion at all, so far as I am aware, that they achieved this form by way of any complementary gift or process of interpretation" (Forbes 1995, 160-161). ${ }^{13}$ To sum up, it is likely that the Montanist ecstasy described by the heresiology

13 See Tabbernee 2007, 94-97, for a detailed discussion of glossolalia within Montanist prophecy. 
reflects not a real case of glossolalia but the traditional representation of the false prophet. ${ }^{14}$ In this specific case, the representation of ecstasy assumes contours and definitions which concur to reinforce the opposition between church and heresy by ascribing to the Montanist religious experience the character of falseness and mendacity.

\section{A "phenomenology" of ecstasy}

In his article about the ecstasy of Montanus, Daunton-Fear argues that "Montanist ecstatic trance is thus neither a slanderous fabrication of the opponents of the movement nor yet the normal mode of Christian prophecy" (Daunton-Fear 1982, 649). He states that it simply reflects the second form of trance, that is to say, the so-called "possession", where all the bodily senses are limited and the mind is totally suppressed, so that one cannot even recall what has happened during it. On the other hand, the first form of trance is characterized by "visions and out-of-body experiences": the bodily senses become less functional and active although the mind remains conscious, where one can recall what has happened and communicate it to others. This is, according to DauntonFear, the type of ecstasy ${ }^{15}$ experienced by Peter and Paul and also all the Old Testament prophets. However, Athenagoras describes the Old Testament prophet in ecstasy as a man inspired by the Spirit which speaks through him like a flautist blowing into a flute (Athenagoras, Legatio pro Christianis 9.1), thereby using the same traditional metaphor that Montanus also employs in one of his oracles reported by Epiphanius (Epiph. Pan. 48.4.1). According to Daunton-Fear, this similarity simply depends on the polemical aim that Athenagoras pursues: wishing to emphasize the superiority of Old Testament prophets, he has to distinguish between pagan poets and philosophers (with their limited intellects) and the biblical prophets who are divinely inspired, and this legitimizes the reduction of their human initiative. Daunton-Fear concludes that Montanus, Prisca and Maximilla could have been influenced by the cult of Apollo in their ecstatic experience (Daunton-Fear 1982, 650).

This approach follows the theological pattern elaborated by the heresiological tradition, which considers the ecstasy of Montanus as a sort of rising of the

14 For a very similar description of false prophecy see the case of Marcus and his prophetesses in Irenaeus, Adversus Haereses I.13.3.

15 I use here the terminology adopted by Daunton-Fear. He states that the word ekstasis "could be used to indicate two different forms of trance: 1) visions and out-of-the-body experiences, and 2) possession” (Daunton-Fear 1982, 649). 
pagan tradition to the surface of the 2nd-century Christianity of Asia Minor. ${ }^{16}$ Stating that the ecstasy of Montanus is different from that experienced by all the other biblical prophets - simply because the latter do not behave like men who are possessed - means that the separation between true and false ecstasy evident in Epiphanius is still valid. The fact that the oracle uttered by Montanus is built on the same metaphor used by Athenagoras to describe the ecstasy of the biblical prophets is by contrast a relevant detail to prove the inconsistency of the traditional separation between the two main forms of ecstatic experiences listed above. ${ }^{17}$ To sum up, the analogy of the vocabulary in different texts describing different forms of ecstasy could attest to a uniformity of this religious experience beyond the theological evaluation lying behind its literary representation.

To examine this, we begin with the description of ecstasy in the most extended account of Montanism within the heresiological tradition. After quoting the aforementioned oracle of Montanus, in which the prophet in ecstasy is compared to a lyre played by the Spirit, Epiphanius affirms that Montanists appeal to the Scriptures to prove the validity of their prophecies, claiming that certain sections from the Scriptures bear a resemblance to themselves. In this case, the biblical verse to which they appeal as evidence of the correctness of their ecstasy is Gen. 2.21, which reports that God "sent an ecstasy upon Adam and he slept”. Epiphanius immediately comments:

But Adam's case was nothing like theirs. In their case God did not mean to fashion a body his reason for putting Adam into a trance - and, in his extreme loving kindness, give them a similar experience. God brought the unconsciousness of sleep upon Adam, not distraction of mind. ${ }^{18}$

According to Epiphanius, there is a difference between the ecstasy experienced by Adam and the ecstasy of Montanus, since the former is like a suspension of bodily senses, as it occurs while sleeping, while the latter is a deprivation of mind. ${ }^{19}$ He then continues:

For it is indeed plain that the sacred scripture was right to call this ecstasy. When someone is asleep, all his senses leave him and take a rest (eis anapausin). Though the sense of sight

16 See Dialexis I.5, where Montanus is presented as the priest of Apollo. For the Greek text I use here the critical edition by Berruto Martone 1999.

17 See Dell'Isola 2015, 198-203, for the investigation of the oracle of Montanus in Pan. 48.4.1, especially regarding its parallels in the early Christian literature; see also Trevett 1996, 83-84; Tabbernee 2007, 93-94; Mader 2012, 193-194.

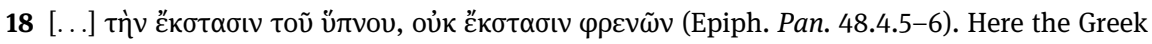
text of the last sentence quoted in the passage.

19 See Nasrallah 2003, 48. 
is there, for example, but does not see; the eye is closed, and the mover in the man, the spirit or soul, is at rest (hēsychazei). If there is an unpleasant odour in the house or even a pleasant one, the sense of smell is there but does not perceive the odour; this sense has departed to take a rest (eis anapausin). If there are bitter, or salty or sweet fluids in the mouth, the sense of taste does not perceive them; it lies in the ecstasy of rest (en ekstasei tès anapauseōs) without doing what it did in the man when he was awake. The ear is there, but the hearing is not functioning as a sense. And if people are talking in the house it often does not hear what anyone says unless the man wakes up; for the time being, its function is suspended. Creatures can be crawling on our bodies, but we do not feel their touch on our bodies unless their onslaught is severe; the whole body has abandoned its activity for the rest of sleep (dia tēn anapausin tou ypnou). For the body is made of earth and envelops the soul, and since God made it serviceable to us in this way, it is allowed a time of withdrawal from its full sensation to a state of rest (eis katastasin anapauseōs). The soul itself does not abandon its function of governance or thought (oude tou fronematos). It often imagines and sees itself as though it were awake, and walks around, does work, crosses the sea, addresses crowds - and sees itself in more situations, and more striking ones, in its dreams. But it is not like a madman, or an ecstatic in a transport (ou mēn kata ton afrainonta kai en ekstasei ginomenon ekstatikon anthrōpon). He takes frightful things in hand while awake in body and soul, and often does grievous harm to himself and his neighbours. He does not know (agnoei) what he is saying and doing, for he has fallen into the ecstasy of folly (en ekstasei afrosynēs).

(Epiph. Pan. 48.4.6-5.8)

In the first form of ecstasy the body sleeps as with an anesthetization of the senses but the mind is awake, while in the ecstasy of the "madman" the mind is completely passive: it abandons the body leaving him without any guidance or control, in a physical and mental state that resembles madness. Thus, true ecstasy is the one where bodily senses are in the state of anapausis (a key-term which occurs five times in the whole passage) and hësychia: this status means a physical condition of rest and relaxation, and especially quiet. By contrast, a false ecstasy is described as an "ecstasy of folly", a state of afrosyne, that is to say, a complete absence of frēn, as the seat of mental faculties, perception, and thought (note that to describe the false ecstatic here the expression ou menn kata ton afrainonta is used). On the one hand, the soul of a true ecstatic never loses its fronēma, an alternative term with the same root of afrosyne, to identify the mind as the seat of thought. On the other hand, the man who falls into a false trance is not able to recall what he has said or done during ecstasy: his mind is in a state of agnoia. The verb agnoeō means "not to perceive or recognize", but since it derives from nous, which means "perception/thought" as well as "understanding/ mind", it also acquires the significance of "absent-mindedness". In this sense, it appears to be very close to the afrosyne cited above.

This semantic field could be emphasized by the combination of afrosyne / agnoia and amathia, the latter being a relevant term in the anonymous account 
of Montanism. That unknown author quotes the words of Miltiades, a writer who had also written a treatise against Montanists:

But the false prophet speaks in ecstasy, after which follow ease and freedom from fear; he begins with voluntary ignorance (ex hekousiou amathias), but turns to involuntary madness of soul (eis akousion manian psychēs), as has been said before. (Eus. HE V.17.2)

Miltiades affirms that the false ecstasy of the Montanist prophets resembles madness, and the way to madness is traced by a particular state of mind that has been described as amathia. This term derives from manthanō ("learn/perceive/understand"), so it acquires the significance of "absence of perception/ understanding" and therefore the same meaning of afrosynē/agnoia.

\section{Philo on the religious experience of ecstasy}

In his article on early Christian prophecy and its relationship with the Ascension of Isaiah, Pier Cesare Bori compares the scene of ecstatic prophecy in Ascension of Isaiah 6 with other descriptions of ecstasy. This comparison serves to trace similarities and differences within an overall literary discourse on this specific religious experience (Bori 1980, 367-389). ${ }^{20}$ One of the texts to which he appeals for the comparison is De specialibus legibus, by Philo of Alexandria. ${ }^{21}$ Certain passages, Bori suggests, reveal themselves as remarkably relevant also to the investigation of ecstasy described by Epiphanius in his personal refutation of Montanism. Philo says:

A prophet possessed by God will suddenly appear and give prophetic oracles. Nothing of what he says will be his own, for he that is truly under the control of divine inspiration (enthousiōn) has no power of apprehension when he speaks but serves as the channel for the insistent words of another's prompting. For prophets are the interpreters of God, who makes full use of their organs of speech to set forth what he wills. ${ }^{22}$

(Philo, De Spec.Leg. 1.65)

20 According to Bori, in Ascension of Isaiah 6 there is no trace of the diffidence, which has its origins in the anti-Montanism struggle, that led to denying the identification of prophecy with ecstasy.

21 See Nasrallah 2003, 36-44, for the investigation of Philo's taxonomy of ecstasy. See also Mader 2012, 69-79.

22 The translation of all the passages from De specialibus legibus (here and elsewhere) is by F.H. Colson. 
He then continues:

For no pronouncement of a prophet is ever his own; he is an interpreter prompted by another in all his utterances, when knowing not (en agnoiai) what he does he is filled with inspiration (enthousiai), as the reason withdraws and surrenders the citadel of the soul to a new visitor and tenant, the Divine Spirit which plays upon the vocal organism and dictates words which clearly express its prophetic message.

(Philo, De Spec.Leg. 4.49)

A further confirmation of this description of the prophet as a passive instrument of God's will can be found in Quis rerum divinarum heres sit:

For a prophet (being a spokesman) has no utterance of his own, but all his utterance came from elsewhere, the echoes of another's voice. The wicked may never be the interpreter of God, so that no worthless person is "God-inspired" (enthousiai) in the proper sense. The name only befits the wise, since he alone is the vocal instrument of God, smitten and played by his invisible hand. ${ }^{23}$

(Philo, Quis Haer. 259)

Two issues are crucial here and combine all the passages cited above:

1) The prophet is just an interpreter who does not say anything of his own, since his words are prompted by God speaking through him;

2) Since the prophet is just an instrument of God's voice, he finds himself in a physical and mental condition of not knowing what he is saying and doing, because his reason "withdraws".

The first issue does not trace the well-defined line of separation between the two main forms of ecstasy elaborated by Epiphanius: in both cases, the divine inspiration presupposes a passive role of the prophet who becomes the bodily instrument of God's voice. On the other hand, the second issue marks a considerable divergence between the two forms of ecstasy: the statement that the passive role of the prophet entails the loss of reason, with the inability to be conscious of what he himself is saying or doing, accords with the second form of ecstasy in the argument of Epiphanius. Furthermore, it is not by chance that Philo uses the term agnoia, which refers to the unawareness of what is being uttered, denoting thus a status of "absent-mindedness".

More significantly, there is another fundamental key term in all three of the aforementioned passages: enthousiazō, meaning "to be inspired or possessed by a god, to be in ecstasy". The verb, with its general significance, occurs in other passages of Christian writings. For example, in Contra Celsum Origen refers to it when describing the usual process of divine inspiration experienced by a Christian

23 Transl. by F.H. Colson and G.H. Whitaker. 
reader of Scripture. ${ }^{24}$ Also in this case, it is no coincidence that the anonymous author in Eusebius employs exactly the same verb to describe the beginnings of Montanus' prophetic activity (Eus. HE V.16.7-8). Such verbal coincidence attests to a common pre-existent vocabulary on ecstasy which all the authors draw on to trace a general description of the ecstatic experience. Ultimately, the same language of ecstasy is here common to Eusebius, Philo, Epiphanius, and Origen; this commonality provides evidence of a shared linguistic substrate at the heart of each literary representation of ecstasy as a religious experience.

\title{
5 Celsus against the Christian prophets
}

\begin{abstract}
'There are many', he says, 'who are nameless, who prophesy at the slightest excuse for some trivial cause both inside and outside temples; and there are some who wander about begging and roaming around cities and military camps; and they pretend to be moved as if giving some oracular utterance. It is an ordinary and common custom for each one to say: "I am God (or a son of God, or a divine Spirit). And I have come. Already the world is being destroyed. And you, O men, are to perish because of your iniquities. But I wish to save you. And you shall see me returning again with heavenly power. Blessed is he who has worshipped me now! But I will cast everlasting fire upon all the rest, both on cities and on country places. And men who fail to realize the penalties in store for them will in vain repent and groan. But I will preserve for ever those who have been convinced by me"”. Then after that he says: 'Having brandished these threats they then go on to add incomprehensible, incoherent, and utterly obscure utterances, the meaning of which no intelligent person could discover; for they are meaningless and nonsensical, and give a chance for any fool or sorcerer to take the words in whatever sense he likes. ${ }^{25}$
\end{abstract}

Celsus, Origen says, is here comparing all the ancient prophets to some other prophets who were still active in his time both in Phoenicia and Palestine. This being said, he does not state their religious identity. Putting aside the question about the real identity of the oracle quoted here, I would like to focus my attention on the language used by Celsus to describe the ecstatic behavior of these prophets.

Here Celsus presents the prophetic words uttered by them as agnōsta ("unknown", "that does not sound familiar"); paroistra ("delirious", "attesting that they are produced by a state of excitement or delirium"); and adēla ("obscure",

\section{Orig. C.Cels. VI.5.}

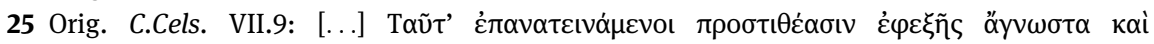

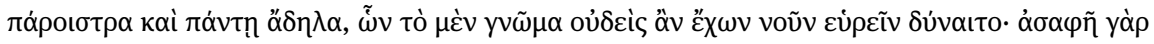

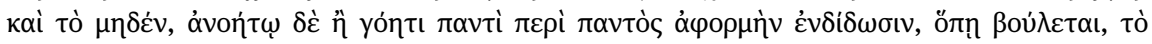
$\lambda \varepsilon \chi \theta \varepsilon \dot{v} v \varphi \varphi \varepsilon \tau \varepsilon \rho i \zeta \varepsilon \sigma \theta \alpha$ เ. Transl. by H. Chadwick. Here the Greek text of the last sentence quoted in the passage. 
"not visible or manifest"). Further, he declares that no reasonable person (oudeis echōn noun) can grasp the true meaning of these words. After that, he goes back again to emphasize the words uttered by the prophets, describing them as asafē ("indistinct" (to the mind), "uncertain", "obscure"). Celsus then concludes with a final sharp assessment that refers to magic, here represented as a negative counterpart of prophecy: namely, a symbol of falsehood in opposition to prophecy, which is obviously marked by a higher level of truth. He affirms that the words uttered by the prophets are so unintelligible that they give "to any unreasonable person" (anoētōi) or "to any magician" (goèti) - thus, to anyone who proves to be a charlatan - the chance to use them as he wishes.

This lexical apparatus, which entails a well-defined semantic field, seems to share a number of elements with the vocabulary of ecstasy in the accounts of Montanism within the heresiological tradition. For example, agnōstos is a derivative form of the verb gignōskō, and as such, it is very similar to agnoia regarding its meaning; anoètos (emphatically stressed here by the expression oudeis echōn noun) derives from nous, so it recalls directly the "absent-mindedness" which the same agnoia refers to.

More strikingly, the overall assessment expressed by Celsus to describe the prophecy of these "inspired persons", whom he attacks in his polemic, appears considerably similar to Epiphanius' comments on the Montanist oracle in Pan. 48.4.1. Celsus presents the prophetic words as obscure, unintelligible, and incomprehensible. Similarly, Epiphanius maintains that the words uttered by Montanus are distorted and meaningless. So much so that they cannot even "stand up".

\section{Conclusion}

In talking about possession as religious experience, Ann Taves affirms “[...] the relationship between trance, a commonplace boundary phenomena, and possession, a social construct, provides a good vantage point for examining the complicated relationship between the psycho-physiological and social dimensions of experience. To differentiate these aspects of the phenomena, anthropologists typically distinguish between the psycho-physiological concept of trance and the cultural concept of possession" (Taves 2009, 78-79). Then after stating that possession does not necessarily require trance in the neurological sense, since there can be trance without possession and possession without being in trance - she concludes that "since the presence of physiologically verifiable trance does not determine whether a performance is successful or not, historical and ethnographic work is required to discover the cultural 
distinctions that subjects and observers use to decide if phenomena are authentic, fake, or pathological in various contexts" (Taves 2009, 81).

In the particular dynamic which links together actual religious performance and the perception of it experienced by observers and narrated by themselves, the role of these observers becomes extremely crucial; this is especially true of all the literary contexts where there is not any first-person narrative by the individual who has directly experienced the religious phenomenon.

In the case of Montanism, it is in the heresiological sources that we can find the only detailed analysis of the ecstasy experienced by the Phrygian prophets and prophetesses. That means the description of ecstasy is included within a broader literary context aiming to refute the religious experience of the heretics. However, the heresiological description of Montanist ecstasy stands as an exhaustive and detailed report. It traces the entire articulation of the ecstatic process throughout its course. In some cases, as in Panarion 48, the description of ecstatic prophecy even has been included within a broader theoretical discussion about the main forms of ecstasy, thus acquiring further consistency and efficacy. There is therefore a tension between ecstasy as a real experience and the literary constraints which seek to depict it according to a polemical intent. In this way, a religious experience which is real and observable tends to be subject to the domain of the controversial discussion. This means that the polemist imposes a sort of overlapping between a neutral description of ecstasy and a personal evaluation of it.

However, the vocabulary used in the traditional descriptions of Montanist ecstasy allows us to establish a comparison with other texts that also contain descriptions of ecstatic prophecy. The similar language in different writings seems to attest a uniformity in narrating the same religious experience. Therefore, the vocabulary becomes the instrument of the deconstruction of the value judgment expressed by the author's personal assessment. In the end, this shows that the concept of "false" related to a religious experience depends entirely on the observer's intentions.

\section{Bibliography}

Aragione, Gabriella 2013. 'L’hérésiologie comme genre littéraire: des traites de controverse aux catalogues d'hérésie.' In Ecrire contre: Quête d'identité, quête de pouvoir dans la littérature des premiers siècles chrétiens, ed. Françoise Vinel. Strasbourg. 95-117.

Aune, David E. 1983. Prophecy in Early Christianity and the Ancient Mediterranean World. Grand Rapids.

Berruto Martone, Anna Maria 1999. Dialogo di un montanista e un ortodosso. Bologna. 
Bori, Pier Cesare 1980. 'L'estasi del profeta: “Ascensio Isaiae” 6 e l'antico profetismo cristiano', Cristianesimo nella storia 1/2. 367-389.

Bremmer, Jan N. 2016. 'The Domestication of Early Christian Prophecy and the Ascension of Isaiah.' In The Ascension of Isaiah, ed. Jan N. Bremmer, Thomas R. Karmann, Tobias Nicklas. Leuven. 1-23.

Cameron, Averil 2005. 'How to Read Heresiology.' In The Cultural Turn in Late Ancient Studies. Gender, Asceticism, and Historiography, ed. Dale B. Martin, Patricia Cox Miller. Durham. 193-212.

Chabot, Jean-Baptiste 1910. Chronique de Michel le Syrien, patriarche jacobite d'Antioche (1166-99). Paris.

Daunton-Fear, Andrew 1982. 'The Ecstasies of Montanus', Studia Patristica 17. 648-651.

Dell'Isola, Maria 2015. 'Il dibattito esegetico su vera e falsa profezia in Epiph. Pan. 48: la costruzione retorica del fenomeno profetico montanista', Adamantius 21. 195-210.

Forbes, Christopher 1995. Prophecy and Inspired Speech in Early Christianity and its Hellenistic Environment. Tübingen.

Gero, Stephen 1977. 'Montanus and Montanism according to a Medieval Syriac Source', Journal of Theological Studies 28. 520-524.

Gilhus, Ingvild S. 2015. 'The Construction of Heresy and the Creation of Identity: Epiphanius of Salamis and His Medicine-Chest against Heretics', Numen 62. 152-168.

Iricinschi, Eduard; Zellentin, Holger M. (eds) 2008. Heresy and Identity in Late Antiquity. Tübingen.

Le Boulluec, Alain 1985. La notion d'hérésie dans la littérature grecque $I I^{e}-I I l^{e}$ siècles. Paris.

Lieu, Judith M. 2015. Marcion and the Making of a Heretic: God and Scripture in the Second Century. Cambridge.

Lyman, Rebecca 2007. 'Heresiology: The Invention of "Heresy" and "Schism".' In The Cambridge History of Christianity, ed. Augustine Casiday, Frederick W. Norris. Cambridge. 296-313.

Mader, Heidrun E. 2012. Montanistische Orakel und kirchliche Opposition: Der frühe Streit zwischen den phrygischen 'neuen Propheten' und dem Autor der vorepiphanischen Quelle als biblische Wirkungsgeschichte des 2. Jh. n.Chr. Göttingen.

Nasrallah, Laura S. 2003. An Ecstasy of Folly: Prophecy and Authority in Early Christianity. Cambridge, MA.

Pourkier, Aline 1992. L'hérésiologie chez Épiphane de Salamine. Paris.

Segal, Alan F. 2006. 'Religious Experience and the Construction of the Transcendent Self.' In Paradise Now: Essays on Early Jewish and Christian Mysticism, ed. April D. DeConick. Atlanta. 27-40.

Shelton, Brian 2015. 'Patristic Heresiology: The Difficulties of Reliability and Legitimacy.' In Orthodoxy and Heresy in Early Christian Contexts: Reconsidering the Bauer Thesis, ed. Paul Hartog. Eugene. 193-212.

Tabbernee, William 2007. Fake Prophecy and Polluted Sacraments: Ecclesiastical and Imperial Reactions to Montanism. Leiden.

Taves, Ann 2009. Religious Experience Reconsidered: A Building-Block Approach to the Study of Religion and Other Special Things. Princeton.

Trevett, Christine 1996. Montanism: Gender, Authority and the New Prophecy. Cambridge. 